\title{
PENGGUNAAN STRATEGI MIND MAPPING DALAM PEMBELAJARAN KOSAKATA BAHASA ARAB
}

\author{
Shofwatul Fu'adah \\ Universitas Ibrahimy Situbondo \\ shofwatulfuadah07@gmail.com
}

\begin{abstract}
:
For muslims, Arabic language is more important than the other languages. One of the ways to understand Arabic is learn about it. Learning strategies have an important role in learning Arabic, including learning vocabulary. But, in reality Many students feel difficult to learn Arabic, especially in mastering mufradat and other materials. One of the reasons is the wrong process when studying mufradat. This paper describes the implementation of mind mapping strategy in learning Arabic vocabulary at Junior High School (SMP) Alam Banyuwangi. This study used a descriptive qualitative approach with three data collection techniques, namely observation, interviews, and documentation. The results showed that mind mapping strategy can help the teachers to solve the problem of learning Arabic, especially to improve students' mastery of Arabic vocabulary. Because mind maps use visual and sensory reminders in a pattern of related ideas. This map evokes original ideas and triggers memories easily.
\end{abstract}

Keyword: Strategy, Mind Mapping, Arabic Vocabularies

\section{PENDAHULUAN}

Bahasa merupakan alat komunikasi dalam kehidupan sehari-hari yang mempunyai fungsi dan peranan yang sangat penting, termasuk juga didalamnya Bahasa Arab. Pentingnya peranan Bahasa Arab bisa dirasakan dalam upaya mempelajari dan memahami serta mengaplikasikan dalam kehidupan tentang ajaran Islam karena pada dasarnya ilmu-ilmu agama Islam ditulis dalam Bahasa Arab apalagi Al-Qur'an dan Hadits yang bagi bangsa Indonesia merupakan bahasa asing.

Bahasa Arab mempunyai fungsi yang sangat istimewa daripada bahasa-bahasa lain. Ditakdirkan sebagai bahasa Al-Qur'an, mempunyai nilai sastra tinggi, yakni mengkomunikasikan kalam Allah yang karenanya mengandung uslub bahasa yang sangat mengagumkan manusia dan tidak akan ada yang bisa menandinginya. ${ }^{1}$ Sedangkan dari dimensi kebahasaan (linguistik), bahasa Arab sebagai alat komunikasi antar personal, antar komunitas, bahkan bahasa Arab sebagai bahasa internasional, karena bahasa Arab merupakan salah satu bahasa resmi PBB. ${ }^{2}$

Tampaknya, orientasi pembelajaran Bahasa Arab semakin lama semakin banyak mengalami perkembangan. Hal ini dibuktikan dengan adanya pembelajaran Bahasa Arab di Indonesia sejak pendidikan anak usia dini (PAUD), atau mulai taman kanak-kanak (TK) hingga perguruan tinggi.

Keberhasilan pembelajaran tidak terlepas dari banyak faktor yang merupakan satu sistem yang tak dapat diabaikan ketika pembelajatan dilaksanakan oleh guru yang memiliki keahlian di bidangnya, sementara siswa-siswanya tidak memiliki kemauan keras

\footnotetext{
${ }^{1}$ Tayar Yusuf dan Saiful Anwar, Metodologi Agama dan Bahasa Arab, (Jakarta: Raja Grafindo Persada, $t$ th), hal. 187

2 Moh. Ainin, Pengembangan Kurikulum dalam Pembelajaran Bahasa Arab, (Malang: Lisan Arabi, 2019), hal. 5
} 
untuk belajar, maka pembelajaran tersebut belum akan mencapai kepada tujuan yang diharapkan. Begitu juga metode pembelajaran yang digunakan akan menentukan keberhasilan suatu pembelajaran. Justru itu seorang guru, atau calon guru wajib memilki keterampilan dalam pengajaran. Mulai dari aktivitas mendesign pembelajaran, metode pembelajaran, sampai kepada evaluasinya. ${ }^{3}$

Beberapa hal yang harusnya menjadi kewajiban yang harus dibenahi oleh para guru utamanya guru Bahasa Arab, diantaranya adalah adanya upaya guru yang sangat besar, kreativitas, media pembelajaran yang memadai, serta menggunakan pendekatan metode-metode dan strategi-strategi pembelajaran yang berhubungan dengan pengajaran bahasa. ${ }^{4}$

Dalam perjalanannya, Bahasa Arab masih menjadi salah satu pelajaran yang kurang diminati oleh pelajar non Arab termasuk pelajar di Indonesia. Akan tetapi, sebenarnya tanggapan siswa yang seperti itu muncul akibat penyeleksian materi, tatacara, dan urutan penyajiannya tidak atau kurang sesuai dengan pelajar Indonesia, sehingga mereka menganggap belajar Bahasa Arab tidak semudah belajar bahasa asing lainnya seperti belajar Bahasa Inggris.

Keterampilan berbahasa dapat diperoleh dengan pembiasaan mempelajari Bahasa Arab meliputi empat keterampilan atau kemahiran yakni kemahiran menyimak (maharatul istima'), kemahiran berbicara (maharatul kalam), kemahiran membaca (maharatul qira'ah) dan kemahiran menulis (maharatul kitabah). Keempat kemahiran berbahasa ini membutuhkan penguasaan kosakata dan ungkapan-ungkapan sederhana/ ibarat yang memungkinkan siswa dapat berkomunikasi.

Namun, kenyataannya kebanyakan yang menjadi faktor penghambat siswa mengalami kesulitan dalam belajar Bahasa Arab adalah perbendaharaan kosakata dan

${ }^{3}$ Dzulkifli, Metodologi Pengajaran Bahasa Arab; Konvensional dan Kontemporer, (Riau: Zanafa Publishing, 2011), hal. 1

4 Fathul Mujib dan Naila Rahmawati, Permainan Edukatif Pendukung Pembelajaran Bahasa Arab (2), (Jogjakarta: Diva Press, 2012), hal. 27 pola kalimat siswa yang masih sangat terbatas. Salah satu penyebabnya adalah proses yang salah ketika mempelajari kosakata. Padahal, kosakata adalah satuan terkecil yang ikut menentukan kekuatan bahasa. ${ }^{5}$ Serta kosakata juga merupakan salah satu unsur bahasa yang harus dikuasai oleh pelajar bahasa asing untuk dapat memperoleh kemahiran berkomunikasi dengan bahasa tersebut. $^{6}$

Banyuwangi Islamic School (BIS) atau yang lebih dikenal dengan nama Sekolah Alam Banyuwangi adalah sekolah yang menjadikan Bahasa Arab sebagai bahasa sehari-hari siswa selain Bahasa Inggris. Selama ini, kebanyakan guru menggunakan cara menghafal dalam proses pembelajaran mufradat/kosakata. Maka jika dalam setiap bab baru ada puluhan kosakata baru dan harus dihafalkan oleh siswa, tidak menutup kemungkinan kosakata yang dihafal sebelumnya akan hilang atau terlupakan, dan begitu seterusnya jika ada kosakata baru lagi.

Sekolah ini kemudian menggunakan strategi mind mapping sebagai solusi untuk mengatasi masalah dalam pembelajaran mufradat serta untuk meningkatkan kemampuan penguasaan kosakata Bahasa Arab siswa yang sebelumnya sangat lemah.

Telah ada beberapa penelitian terdahulu yang membahas tentang penggunaan strategi mind mapping dalam pembelajaran Bahasa Arab. Ahmad Falah pada tahun 2014 melakukan penelitian terkait penggunaan metode mind mapping untuk meningkatkan pemahaman Bahasa Arab tingkat Madrasah, ${ }^{7}$ dan Ikhwan Nur Rois tentang penggunaan mind mapping dalam pembelajaran Bahasa Arab tingkat mutaqaddim, ${ }^{8}$ dua penelitian ini merupakan

${ }^{5}$ Acep Hermawan, Metodologi Pembelajaran Bahasa Arab, (Bandung: PT Remaja Rosdakarya, 2011), hal.64

6 Ahmad Fuad Effendy, Metodologi Pengajaran Bahasa Arab, (Malang: Misykat, 2009), hal. 120

7 Ahmad Falah, Pembelajaran Bahasa Arab berbasis Mind Map Untuk Meningkatkan Pemahaman Bahasa Arab Pada Tingkat Madrasah, Jurnal Arabia, Vol.6 No.1 Januari-Juni 2014, hal.65-81.

8 Ikhwan Nur Rois dan Fahma Reta Putri, Penerapan Strategi Mind Mapping dalam Pembelajaran 
penelitian kualitatif. Kemudian Dinda Anwinda (2020) tentang penerapan mind mapping untuk meningkatkan keterampilan menulis Bahasa Arab siswa dengan menggunakan penelitian tindakan kelas. ${ }^{9}$

Semua penelitian diatas membahas tentang strategi mind mapping dalam pembelajaran Bahasa Arab, dengan tujuan untuk meningkatkan pemahaman Bahasa Arab khususnya pada pembelajaran qawaid dan keterampilan menulis, tidak terfokus pada pembelajaran mufradat saja, serta pada tingkat pembelajar yang berbeda yakni tingkat mutaqaddim. Selanjutnya Ikhwan menyimpulkan bahwa mind mapping sangat bermanfaat dalam pembelajaran Bahasa Arab dan suasana belajar menjadi kondusif. Serta strategi ini efektif dan relevan digunakan dalam pembelajaran tingkat mutaqaddim dikarenakan para siswa telah mendapatkan semua materi lebih dahulu, lalu pendidik menggunakan strategi ini untuk dapat membuat ringkasan dari materi-materi yang telah diajarkan.

Adapun penelitian ini membahas tentang penggunaan mind mapping dalam pembelajaran kosakata Bahasa Arab/ mufradat. Karena mufradat merupakan unsur bahasa yang penting dan sangat berpengaruh pada kemahiran berbahasa selanjutnya. Namun pada prakteknya, pembelajaran mufradat ini dilakukan dengan proses yang kurang menarik perhatian dan minat siswa seperti dengan cara menghafal, dll. Penelitian ini dilakukan pada tingkat pemula di sekolah umum (bukan madrasah) yakni Sekolah Menengah Pertama Ma'had Alam Banyuwangi yang notabene tidak semua siswa memiliki basic kemampuan Bahasa Arab yang sama bahkan ada yang benar-benar pemula dalam belajar Bahasa Arab, tentunya butuh strategi pembelajaran yang menyenangkan serta dapat menarik minat dan

Bahasa Arab Bagi Mutaqaddim, Prosiding Konferensi Nasional Bahasa Arab VI (KONASBARA), Oktober 2020, hal 75-86.

9 Dinda Anwinda, Penerapan Metode Mind Mapping Untuk Meningkatkan Keterampilan Menulis Bahasa Arab Siswa kelas XII SMK Tritech Bhayangkara Medan, (Medan, UIN Sumatera Utara, 2020). perhatian siswa dalam mempelajari Bahasa Arab khususnya mufradat.

Berpijak dari permasalahan tersebut, maka penulis mencermati lebih jauh, mendeskripsikan, dan menganalisis penggunaan strategi pembelajaran Bahasa Arab khususnya strategi mind mapping dalam pembelajaran mufradat/kosakata Bahasa Arab siswa yang diterapkan di SMP Alam Genteng-Banyuwangi.

\section{METODE PENELITIAN}

Jenis penelitian yang dilakukan adalah menggunakan pendekatan kualitatif deskriptif. Penelitian kualitatif bermaksud untuk memahami fenomena tentang apa yang dialami oleh subjek penelitian misalnya prilaku, persepsi, motivasi, tindakan, dll. ${ }^{10}$ Peneliti berusaha memahami peristiwaperistiwa dan hal-hal yang berkaitan dengan orang-orang yang peneliti amati yang berada dalam situasi tetentu.

Penelitian ini mengambil lokasi di kelas VIII SMP Ma'had Alam Banyuwangi Islamic School (BIS) Genteng - Banyuwangi karena sekolah tersebut termasuk salah satu dari sekolah swasta yang menggunakan strategi mind mapping dalam pembelajarannya termasuk Bahasa Arab. Sehingga diharapkan dapat menunjang kegiatan pembelajaran di sekolah tersebut. Adapun beberapa informan dalam penelitian ini diantaranya kepala sekolah, guru mata pelajaran Bahasa Arab, kaur kurikulum, siswi, guru sejawat.

Dalam mengumpulkan data, penelitian ini menggunakan teknik observasi, wawancara dan documenter. Miles dan Huberman mengemukakan bahwa aktivitas dalam analisis data kualitatif dilakukan secara interaktif dan berlangsung secara terus menerus sampai tuntas, sehingga datanya sudah jenuh. Aktivitas dalam analisis data,

${ }^{10}$ Lexy J. Moleong, Metodologi Penelitian Kualitatif, (Bandnug: PT Remaja Rosdakarya, 2011), hal.6 
yaitu data reduction, data display, dan conclusion drawing/verification. ${ }^{11}$

\section{HASIL DAN PEMBAHASAN}

\section{Mind Mapping (Peta Pikiran)}

Mind Mapping atau selanjutnya disebut peta pikiran merupakan teknik pemanfaatan keseluruhan otak dengan menggunakan citra visual dan prasarana grafis lainnya untuk membentuk kesan mendalam. $^{12}$

Mind mapping adalah cara untuk menempatkan informasi kedalam otak dan mengambil informasi ke luar dari otak. Mind map adalah cara mencatat yang kreatif, efektif, dan secara harfiah akan "memetakan" pikiran-pikiran kita. Mind map juga sangat sederhana. ${ }^{13}$ Pembelajaran dengan strategi peta pikiran ini baik digunakan untuk pengetahuan awal siswa atau untuk menemukan alternatif jawaban. ${ }^{14}$

Peta pikiran ini merupakan teknik pencatat yang dikembangkan oleh Tony Buzan dan didasarkan pada riset tentang bagaimana cara kerja otak. Peta pikiran memiliki ide pokok atau yang disebut dengan ide sentral yang berada ditengah tengah kertas kemudian memiliki cabangcabang yang bersumber dari ide pokok tersebut, inilah salah satu konsep yang didasarkan pada cara kerja otak yakni membentuk suatu pola yang bercabang terbentuk dari ide-ide yang saling berkaitan dari ide sentral. Peta ini membangkitkan ide-ide baru dan memicu ingatan yang mudah. Oleh karena itu, peta pikiran sebagai teknik pencatatan yang

11 Sugiyono, Metode Penelitian Kuantitatif Kualitatif dan R\&D, (Bandung: Penerbit Alfabeta, 2011), hal.246

12 Bobby DePorter \& Mike Hernacki, Quantum Learning:Membiasakan Belajar Nyaman dan Menyenangkan. Terjemahan Alwiyah Abdurrahman, (Bandung: Kaifa,2011), hal.153

13 Tony Buzan, Buku Pintar Mind Map. Terjemahan Susi Purwoko, ( Jakarta: PT Gramedia Pustaka Utama, 2013), hal.4

14 Zainal Aqib, Model-model, Media dan Strategi Pembelajaran Kontekstual (Inovatif), (Bandung: Penerbit Yrama Widya, 2013), hal.23 baru ini akan sangat membantu guru sebagai salah satu cara belajar atau strategi belajar yang dapat diajarkan pada siswa dalam proses belajar mengajar. Tentunya teknik pencatatan mind mapping ini akan memiliki banyak perbedaan dengan teknik pencatatan tradisional yang selama ini digunakan oleh siswa.

Berikut ini adalah beberapa perbedaan pencatatan biasa dan pencatatan mind mapping:

\begin{tabular}{|l|l|}
\hline \multicolumn{1}{|c|}{$\begin{array}{c}\text { CATATAN } \\
\text { BIASA }\end{array}$} & MIND MAPPING \\
\hline $\begin{array}{l}\text { Berupa tulisan } \\
\text { saja }\end{array}$ & $\begin{array}{l}\text { Berupa tulisan, } \\
\text { garis, simbol dan } \\
\text { gambar }\end{array}$ \\
\hline $\begin{array}{l}\text { Hanya memiliki } \\
\text { satu warna }\end{array}$ & $\begin{array}{l}\text { Memiliki banyak } \\
\text { warna }\end{array}$ \\
\hline $\begin{array}{l}\text { Membutuhkan } \\
\text { waktu yang lama } \\
\text { untuk mengulang } \\
\text { pelajaran }\end{array}$ & $\begin{array}{l}\text { Membutuhkan } \\
\text { waktu yang singkat } \\
\text { atau lebih pendek } \\
\text { untuk mengulang } \\
\text { pelajaran }\end{array}$ \\
\hline $\begin{array}{l}\text { Melibatkan otak } \\
\text { kiri saja }\end{array}$ & $\begin{array}{l}\text { Memadukan kedua } \\
\text { belahan otak (kiri } \\
\text { dan kanan) }\end{array}$ \\
\hline
\end{tabular}

Tabel 1 : Perbedaan pencatatan biasa dengan pencatatan mind mapping.

Berdasarkan pada perbedaan tersebut, dalam pola pencatatan yang biasa, siswa membuat catatan yang monoton dan biasa saja, tidak ada hal-hal yang membuatnya menarik ketika membacanya atau ketika mengulang pelajaran, seperti tidak adanya gambar, ditulis dengan pen yang berwarna warni, atau membuat cabang-cabang dan panahpanah yang saling berkaitan, sehingga cara penerimaan informasinya akan kurang efektif karena tidak adanya semangat ketika belajar yang mempengaruhi proses penguatan daya ingat.

Belajar dengan peta pikiran ini akan menjadikan pembelajaran dan proses belajar siswa lebih efektif karena seperti yang diungkapkan oleh DePorter bahwa diantara manfaat pencatatan ini adalah 
dapat memusatkan perhatian dan meningkatkan pemahaman. Karena dengan adanya ide sentral yang memiliki cabang-cabang juga tampilan yang menarik, siswa dapat belajar dengan menyenangkan.

Adapun dalam pembuatannya, peta pikiran atau mind mapping memiliki tujuh langkah sebagai berikut: ${ }^{15}$

1) Mulailah dari bagian TENGAH kertas kosong yang sisi panjangnya diletakkan mendatar. Mengapa? Karena memulai dari tengah memberi kebebasan kepada otak untuk menyebar ke segala arah dan untuk mengungkapkan dirinya lebih bebas dan alami.

2) Gunakan GAMBAR atau FOTO untuk ide sentral anda. Karena sebuah gambar bemakna seribu kata. Sebuah gambar sentral akan membuat kita fokus, membantu kita berkonsentrasi, dan mengaktifkan otak kita.

3) Gunakan WARNA. Gunakan warna yang berbeda-beda untuk tiap-tiap cabang. Warna membuat mind mapping ini lebih hidup dan memicu pemikiran kreatif dan menyenangkan.

4) Hubungkan cabang-cabang utama ke gambar pusat dan hubungkan cabangcabang tingkat dua dan tiga ke tingkat satu dan dua, dan seterusnya. Selanjutnya Bobby Deporter menjelaskan dalam bukunya bahwa "...Jumlah cabangnya akan bervariasi, tergantung jumlah gagasan atau segmen..."

5) Buatlah garis hubung yang MELENGKUNG bukan garis LURUS. Karena garis lurus akan membosankan otak.

6) Gunakan satu kata kunci untuk setiap baris.

7) Gunakan gambar dalam tiap kata kunci.

Untuk mencapai pembelajaran yang tuntas diperlukan strategi belajar yang efektif diterapkan pada siswa. Jika sebelumnya dijelaskan tentang teknik

\footnotetext{
15 Tony Buzan, Buku Pintar Mind Map...
}

tatacara membuat catatan dengan menggunakan strategi mind mapping, maka berikut ini adalah langkah langkah penggunaan strategi mind mapping dalam proses pembelajaran $:^{16}$

1) Guru menyampaikan kompetensi yang ingin dicapai.

2) Guru menyampaikan materi sebagaimana biasa (guru mengemukakan permasalahan yang akan ditanggapi siswa)

3) Buatlah kelompok yang anggotanya 23 orang/ kelompok berpasangan 2 orang, hal ini dilakukan ntuk mengetahui daya serap siswa.

4) Tiap kelompok mencatat alternatif jawaban/ menginventarisasi hasil diskusi (membuat catatan-catatan kecil).

5) Tiap kelompok (atau diacak kelompok tertentu) membaca hasil diskusinya, guru mencatat di papan dan mengelompokkan sesuai kebutuhan guru.

6) Guru mengulangi/menjelaskan kembali materi yang kiranya belum dipahami siswa.

7) Kesimpulan/penutup.

\section{Pembelajaran Kosakata/mufradat}

Kosakata/ mufradat adalah satuan terkecil yang ikut menentukan kekuatan bahasa. ${ }^{17}$ Mufradat merupakan salah satu unsur bahasa yang menjadi bagian penting dari komponen bahasa, dan merupakan salah satu dasar pengembangan kemampuan berbahasa Arab selanjutnya, baik lisan maupun tertulis. Perbendaharaan dan penguasaan mufradat yang memadai dapat menunjang seseorang dalam berkomunikasi lisan dan tertulis dengan bahasa Arab.

Dalam pelaksanaannya, kebanyakan metode atau cara yang digunakan oleh guru dalam pembelajaran

16 Zainal Aqib, Model-model,Media dan Strategi ... hal. 23

17 Abdul Hamid, Mengukur Kemampuan Bahasa Arab Untuk Study Islam, (Malang: UIN Maliki, 2010), hal.33 
mufradat adalah dengan dengan cara menghafal. Jika dalam setiap bab baru ada puluhan kosakata baru dan harus dihafalkan oleh siswa tidak menutup kemungkinan kosakata yang dihafal sebelumnya akan hilang atau terlupakan, dan begitu seterusnya jika ada kosakata baru lagi.

Dalam mendapatkan makna kata/mufradat, maka sebaiknya guru dengan sedapat mungkin menghindari terjemahan ketika memberikan arti kata kepada siswa seperti menunjukkan gambar, memberikan ciri-ciri, dan menceritakan bendanya, kecuali kalau tidak ada jalan lain. ${ }^{18}$ Seperti kata-kata yang bersifat abstrak, sehingga sulit dijelaskan maknanya dengan teknik lainnya.

Hal ini senada dengan yang diungkapkan Effendy dalam bukunya bahwa cara atau teknik untuk menghindari terjemahan yang bisa digunakan guru diantaranya dengan menjelaskan sinonim atau antonim kata tersebut, menunjukkan gambar, benda asli atau tiruannya, peragaan, mengulang-ulang bacaan (takrir al-qira'ah), dan terakhir mencari dalam kamus. ${ }^{19}$

\section{Penggunaan strategi mind mapping dalam pembelajaran kosakata Bahasa Arab di Sekolah Alam Banyuwangi}

Sekolah Alam adalah sekolah yang menerapkan sistem full day school dan boarding school. Menggunakan kurikulum nasional (dinas) dengan keunggulan lokal. Pembelajaran melalui Pendekatan Multiple Intelligence, contextual learning, quantum learning, dan pembelajaran berbasis multimedia. Hampir seluruh aktivitas dilakukan di sekolah dan asrama, namun aktivitas anak didik tidak terbatas di ruangan kelas.

18 Taufik, Pembelajaran Bahasa Arab MI (Metode Aplikatif \& Inovatif Berbasis ICT, (Surabaya: Penerbit PMN, 2012), hal. 68

19 Ahmad Fuad Effendy, Metodologi Pengajaran...hal. 123
Kegiatan belajar, bermain, makan dan beribadah dikemas dalam satu sistem pendidikan yang menyenangkan. Seluruh aktivitas di Sekolah Alam menggunakan Bahasa Inggris dan Bahasa Arab sebagai bahasa sehari hari.

Banyak metode dan strategi yang digunakan sekolah ini untuk mendukung pelaksanaan pembelajaran yang menyenangkan, diantaranya metode Role Playing, menyanyi, game, mind mapping, dll. Namun, penelitian ini hanya terbatas pada penggunaan strategi mind mapping dalam pembelajaran kosakata Bahasa Arab siswa. Dari data yang terkumpul, berikut beberapa data yang ditemukan oleh peneliti yang berkaitan dengan penggunaan strategi mind mapping baik yang diperoleh dari observasi, dokumentasi, dan wawancara.

Dalam Perencanaan pembelajaran banyak cara yang dilakukan oleh guru baik sebelum maupun ketika proses kegiatan belajar mengajar agar pembelajaran berlangsung efektif, sehingga tujuan dan hasil pembelajaran dapat dicapai dengan maksimal. Banyak hal yang harus dipersiapkan guru guna mencapai tujuan pembelajaran yang diharapkan. Di antara yang harus dipersiapkan guru adalah perangkat pembelajaran mencakup silabus, RPP, bahan evaluasi dll.

Guru harus benar-benar menguasai metode dan media apa saja yang akan ia gunakan agar siswa turut aktif dan senang ketika belajar. Karena dalam pelaksanaannya, guru memang tidak hanya menggunakan strategi mind mapping dalam satu materi pelajaran. Misalnya dalam pertemuan kali ini yang dibahas adalah tentang materi "البيت", kosakata yang telah dibuat peta oleh masing masing murid, kemudian dijadikan sebuah lagu sesuai dengan kelompok masing masing berikut dibuat gerakan yang sesuai dengan kosakata yang ada. Ini semua dikerjakan perkelompok, sehingga siswa berusaha mencari jawaban dan memecahkan masalah bersama dan 
kemudian mempresentasikan di depan kelas. Strategi ini tidak hanya membuat siswa mudah menghafal kosakata namun mereka termotivasi untuk berlomba-lomba dengan kelompok lain untuk menjadi lebih baik.

Mengenai teknik dan alat-alat yang digunakan untuk membuat mind mapping, yakni kertas hvs, dan spidol warna warni. Ibu Rahayu Eviyanti mengungkapkan bahwa mind mapping mirip dengan peta konsep, hanya bedanya di mind mapping ada gambar, warna dan menggunakan garis lengkung di setiap cabangnya. Itu semua melibatkan otak kanan sehingga siswa senang ketika belajar.

Adapun langkah - langkah penggunaan strategi mind mapping dalam pembelajaran kosakata Bahasa Arab di SMP Alam BIS Genteng, sebagai berikut:

1) Guru menyampaikan kompetensi yang ingin dicapai

2) Guru melakukan appersepsi (mengingat materi sebelumnya dengan bernyani lagu yang dibuat pada pertemuan sebelumnya)

3) Guru membahas materi baru ( tentang "البيت", berikut kosakatakosakata yang ada didalamnya), dan guru mencontohkan cara bacanya.

4) Siswa dibentuk berkelompok untuk membuat mind mapping (@ kelompok 5 orang).

5) Setiap siswa mempresentasikan map/peta hasil karyanya masingmasing secara bergiliran di kelompok masing-masing.

6) Setiap kelompok membuat permainan untuk materi yang sudah diajarkan (membuat lagu kosakata berdasarkan kreasi masing-masing kelompok dan gerakan yang sesuai kosakata, seperti غرفة ada kosakata البيت dalam materi النوم, siswa mengucapkan kosakata tersebut sambil bernyanyi sambil mempraktekkan gerakannya dengan meletakkan kedua tangannya dibawah pipi menggambarkan orang yang sedang tidur).

7) Setiap kelompok atau kelompok secara acak mempresentasikan hasil diskusi kelompoknya (map/peta yang dibuat berikut lagu dan gerakannya).

8) Guru memberi penguatan dan menjelaskan kembali isi materi yang belum dipahami siswa dengan membuat mind mapping (versi guru).

9) Evaluasi (tes lisan kosakata yang sudah dipelajari).

10) Kesimpulan/penutup.

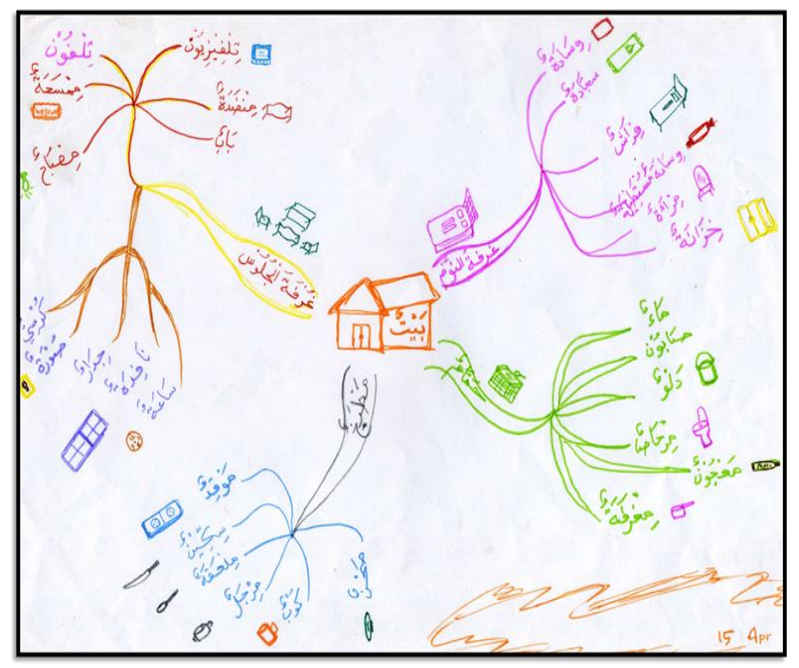

Gambar 1: hasil Mind Mapping tentang البيت yang dibuat siswa

Beberapa teknik pembelajaran mufradat yang dijelaskan oleh Ahmad Fu'ad Effendy sebagaimana tersebut diatas, seperti mengulang-ulang bacaan, adanya gambar dalam setiap kosakata di tiap-tiap cabang peta, serta adanya peragaan ketika menjelaskan makna kosakata, telah digunakan dalam pembelajaran mufradat dengan menggunakan strategi mind mapping di Sekolah Alam Banyuwangi.

4. Kemampuan kosakata Bahasa Arab siswa setelah menggunakan strategi Mind Mapping

Strategi mind mapping adalah teknik pencatatan yang sangat efektif digunakan untuk pembelajaran kosakata Bahasa Arab. Sebagaimana diungkapkan 
oleh Bapak Suyanto Nurul Ikhwani (guru Bahasa Arab) bahwa siswa dapat menguasai, mempraktekkan, membuat mapping sendiri, dan mereka menghafal kosakata dengan sendirinya tanpa merasa jenuh, terpaksa, dan tertekan. Malah sebaliknya, mereka senang karena mempelajarinya dengan fun.

Sesuai dengan yang dipaparkan dalam paparan data sebelumnya, Siswa lebih cepat menghafal dan mengingat, karena dengan mengingat gambar mereka cepat mengingat kosakatanya. Mind mapping melibatkan otak kanan dan otak kiri, tidak seperti catatan biasa yang hanya melibatkan otak kiri. Mind mapping memadukan keduanya. Gambar dan warna melibatkan otak kanan, dan juga ada tulisan yang melibatkan otak kiri.

Hal ini sesuai dengan yang dipaparkan dalam pendahuluan, bahwa peta pikiran ini jauh lebih mudah daripada metode pencatatan tradisional karena ia mengaktifkan kedua belahan otak (kanan dan kiri). Otak manusia seringkali mengingat informasi dalam bentuk gambar, simbol, suara, bentuk-bentuk, dan perasaan. $^{20}$

Strategi mind mapping dapat membantu siswa dalam meningkatkan perbendaharaan kosakata Bahasa Arab. Penggunaan strategi ini membantu siswa dalam mempelajari kosakata Bahasa Arab sehingga kemampuan kosakata mereka lebih baik. Mereka lebih cepat dalam menghafal dan mengingat kosakata/mufradat, karena dengan guru menyebutkan nama suatu benda dalam bahasa Indonesia atau menunjuk benda asli dan gambar yang ada di peta pikiran itu membuat mereka lebih cepat menyebut nama mufaradatnya. ${ }^{21}$

20 Bobby DePorter dan Mike Hernacki, Quantum Learning... h.153

21 Shofwatul Fu'adah, "Tathbîq Tiknûlûjiyâ (Istirâtîjiyah al-Kharîthah al-Dzihniyah) li Hilli Musykilah Ta'lîm Mufradât al-Lughah al-'Arabiyah Lada Thullâb al-Fashl al-Sâbi' fî̀ al-Madrasah alTsânawiyah "Nurul Jadid Banyuputih - Situbondo" “, Jurnal Alibbaa', Vol.1, No.2 (Juli 2020), hal 201-218, https://doi.org/10.19105/alb.v1i2.3572
Sebelum menggunakan strategi mind mapping, pembelajaran Bahasa Arab yang ada di sekolah ini berlangsung dengan hasil yang kurang baik (tidak begitu bagus). Ini terlihat dari nilai Bahasa Arab siswa sebelum menggunakan strategi mind mapping pada kelas VIII yang memiliki nilai rata rata kelas dibawah KKM 7,5.

Namun, setelah guru menggunakan strategi ini, murid mengikuti pembelajaran dengan perasaan senang, mereka antusias mengikuti pelajaran karena strategi ini menyenangkan. Berdasarkan hasil wawancara peneliti bersama kepala sekolah, guru Bahasa Arab, para murid, kaur kurikulum, dan guru sejawat, dapat ditarik benang merah bahwa penggunaan strategi ini mendapat respon yang baik serta mempengaruhi pada penguasaan kosakata Bahasa Arab siswa. Peneliti juga mengikuti proses pembelajaran hingga pelaksanaan tes dengan menggunakan strategi mind mapping.

Kemampuan penguasaan kosakata Bahasa Arab siswa dengan penggunaan strategi mind mapping ini sangat bagus dan perbendaharaan kosakatanya meningkat. Ini didukung dari nilai semester ganjil siswa yang rata-rata nilainya diatas KKM yakni 7,5 (80-95).

Hal ini menambah dan menguatkan temuan sebelumnya bahwa strategi mind mapping ini tidak hanya efektif dan relevan digunakan pada tingkat mutaqaddim saja, namun juga sangat efektif digunakan pada pembelajar Bahasa Arab tingkat pemula khususnya pada pembelajaran mufradat.

\section{Faktor pendukung dan penghambat dalam pembelajaran kosakata/mufradat serta solusi pemecahannya}

a. Faktor Pendukung

Adapun faktor-faktor yang mendukung dalam pelaksanaan pembelajaran mufradat di Sekolah Alam Banyuwangi ini sebagai berikut; 1) Guru yang menguasai metode, pandai menguasai/mengelola kelas, kreatif, inovatif dan terus 
mengembangkan dan menggali informasi baru. 2) Sarana dan prasarana lengkap. 3) Komitmen siswa untuk mau segera bisa dan komunitas berbahasa di asrama/ma'had. 4) Lingkungan alami yang bersatu dengan alam. 5) Kualitas pembelajaran, kerjasama yang baik antara guru, murid dan aparat sekolah.

6) Suasana pembelajaran yang menyenangkan, dan belajar di ruang terbuka.

b. Faktor penghambat

Berikut beberapa kendala yang dihadapi di sekolah Alam Banyuwangi; 1) Kemampuan beberapa siswa yang tidak memiliki basic / latar belakang pendidikan agama yang cukup sebelum masuk Sekolah Alam, sehingga mereka merasa kesulitan membaca tulisan Arab. 2) Beberapa siswa yang menunda-nunda tugas sehingga tidak segera selesai.

Namun berdasarkan observasi dan data yang didapat dari wawancara bersama guru Bahasa di sekolah ini mengungkapkan bahwa tidak ada hambatan yang besar, karena jika ditemukan suatu kendala maka akan segera dicarikan solusinya secara bersama baik antara sekolah, guru dan murid.

\section{SIMPULAN}

Penggunaan strategi mind mapping dalam pembelajaran mufradat / kosakata Bahasa Arab siswa di Sekolah Alam BIS Genteng-Banyuwangi memiliki beberapa tahapan dan langkah langkah pembelajaran yang sama dengan langkah-langkah yang terdapat dalam buku, seperti guru memulai dengan menyampaikan kompetensi yang akan dicapai hingga penutup/kesimpulan. Perbedaannya hanya guru Bahasa Arab di sekolah alam mengkombinasikan strategi mind mapping tersebut dengan game dan menyanyi. Teknik pembuatan catatan dengan strategi mind mapping pun sama dengan teori yang dikembangkan oleh Tony Buzan yakni menggunakan pen yang berwarna warni, kertas, ada garis lengkung yang memancar dari pusat (ide sentral), ada gambar di setiap cabang, dan lain-lain.

Penggunaan strategi mind mapping dalam pembelajaran kosakata dapat meningkatkan perbendaharaan kosakata bahasa Arab siswa. Siswa lebih cepat menghafal dan mengingat, karena dengan mengingat gambar mereka cepat mengingat kosakatanya. Mind mapping melibatkan otak kanan dan otak kiri, tidak seperti catatan biasa yang hanya melibatkan otak kiri. Mind mapping memadukan keduanya. Gambar, warna dan garis lengkung melibatkan otak kanan, dan juga ada tulisan yang melibatkan otak kiri. Penggunaan strategi mind mapping sangat efektif dalam pembelajaran mufradat. kemampuan siswa khususnya dalam perbendaharaan kosakata Bahasa Arab terus meningkat dan sangat bagus, dan ini bisa dilihat dari hasil belajar siswa yang nilainya rata-rata diatas nilai kriteria ketuntasan minimal (KKM) yakni diatas 7,5.

\section{DAFTAR PUSTAKA}

Ainin, Moh. Pengembangan Kurikulum dalam Pembelajaran Bahasa Arab, (Malang: Lisan Arabi, 2019)

Anwinda, Dinda. Penerapan Metode Mind Mapping Untuk Meningkatkan Keterampilan Menulis Bahasa Arab Siswa kelas XII SMK Tritech Bhayangkara Medan, (Medan, UIN Sumatera Utara, 2020).

Aqib, Zainal. Model-model, Media dan Strategi Pembelajaran Kontekstual (Inovatif). (Bandung: Penerbit Yrama Widya, 2013)

Buzan, Tony. Buku Pintar Mind Map. Terjemahan Susi Purwoko. (Jakarta: PT Gramedia Pustaka Utama, 2013).

DePorter, Bobby \& Mike Hernacki. Quantum Learning:Membiasakan Belajar Nyaman dan Menyenangkan. Terjemahan Alwiyah Abdurrahman (Bandung: Kaifa, 2011). 
Dzulkifli. Metodologi Pengajaran Bahasa Arab; Konvensional dan Kontemporer. (Riau: Zanafa Publishing, 2011).

Effendy, Ahmad Fuad. Metodologi Pengajaran Bahasa Arab. (Malang: Misykat, 2009).

Falah, Ahmad. Pembelajaran Bahasa Arab berbasis Mind Map Untuk Meningkatkan Pemahaman Bahasa Arab Pada Tingkat Madrasah, Jurnal Arabia, Vol.6 No.1 Januari-Juni 2014, hal.65-81.

Fu'adah, Shofwatul. "Tathbîq Tiknûlûjiyâ (Istirâtîjiyah al-Kharîthah alDzihniyah) li Hilli Musykilah Ta'lîm Mufradât al-Lughah al-'Arabiyah Lada Thullâb al-Fashl al-Sâbi' fî alMadrasah al-Tsânawiyah "Nurul Jadid Banyuputih -Situbondo"', Jurnal Alibbaa', Vol.1, No.2 (Juli 2020), hal. 201-218,

https://doi.org/10.19105/alb.v1i2.3572

Hamid, Abdul. Mengukur Kemampuan Bahasa Arab Untuk Study Islam. (Malang: UIN Maliki, 2010).

Hermawan, Acep. Metodologi Pembelajaran Bahasa Arab. (Bandung: PT Remaja Rosdakarya, 2011).

Moleong, Lexy J. Metodologi Penelitian Kualitatif. (Bandung:PT Remaja Rosdakarya, 2011).

Mujib, Fathul dan Naila Rahmawati. Permainan Edukatif Pendukung Pembelajaran Bahasa Arab(2). (Jogjakarta : DIVA Press, 2012).

Nuha, Ulin. Metodologi Super Efektif Pembelajaran Bahasa Arab. (Jogjakarta: Diva Press, 2012).

Rois, Ikhwan Nur dan Fahma Reta Putri. Penerapan Strategi Mind Mapping dalam Pembelajaran Bahasa Arab Bagi Mutaqaddim, Prosiding Konferensi Nasional Bahasa Arab VI (KONASBARA), Oktober 2020, hal 7586.
Sugiyono. Metode Penelitian Kuantitatif Kualitatif dan $R \& D$. (Bandung: Penerbit Alfabeta, 2011).

Taufik. Pembelajaran Bahasa Arab MI (Metode Aplikatif \& Inovatif Berbasis ICT. (Surabaya: Penerbit PMN, 2012).

Yusuf, Tayar dan Saiful Anwar. Metodologi Agama dan Bahasa Arab. (Jakarta: PT Raja Grafindo Persada, 1995) 